\title{
16 Social Enterprises in France, Portugal and Spain
}

\author{
Between Path Dependence and \\ Institutional Creation?
}

\author{
Francesca Petrella, Nadine Richez-Battesti, \\ Marta Solórzano-García and \\ Sílvia Ferreira
}

\section{Introduction}

Social enterprise (SE) is a notion that has been little discussed in France, Spain and Portugal by comparison with other national contexts. In this chapter, we first explain that this situation can be accounted for by a strong social-economy tradition in these three countries-which also share the fact that the social economy as a sector has recently been institutionalised through the adoption of a specific law (in 2011 in Spain, 2013 in Portugal and 2014 in France). A majority of French, Spanish and Portuguese organisations that display the characteristics of the ideal-typical social enterprise such as they have been described in the EMES approach are recognised as social-economy organisations. Nevertheless, in the three countries, the notion of social enterprise is currently at the heart of important debates.

This chapter compares the emergence and development of social enterprise in France, Spain and Portugal, which is linked, to a large extent, to the social-economy tradition. These countries have also experienced the emergence of new initiatives, promoted by citizens willing to democratise society and contribute to its social transformation through solidarity practices that do not always adopt social-economy legal forms or traditions. Most of these initiatives are considered today as part of the solidarity economy. Finally, more recently, these countries have seen the emergence of socially innovative and more market-oriented enterprises, which are often described as social enterprises.

The guiding hypothesis of this chapter is that the notion of social enterprise, as initially conceptualised within the EMES International Research Network (Defourny 2004), is scarcely used in the three countries because it does not correspond to a stabilised approach and takes different forms and meanings. Building upon the country reports, we analyse social enterprises as organisations that are located between three poles that coexist in France, Spain and Portugal: the social economy, the solidarity economy and social entrepreneurship. 


\section{Petrella, Richez-Battesti et al.}

The criteria traditionally defining the social economy in France, Spain and Portugal are as follows: objective of serving the members or the community rather than making profit; managerial autonomy; democratic control by the members; primacy of persons and social objective over capital in the distribution of surpluses (CWES 1990; CEP-CMAF 2002). The definition of the social economy also takes into consideration the legal forms of the organisations (associations, cooperatives, mutuals, etc.). These criteria are included in these countries' framework laws, in the form of principles and legal forms.

The solidarity economy brings together all the activities contributing to the democratisation of the economy through citizens' involvement. It considers these activities from the point of view of their dual-economic and political-dimension (Dacheux and Laville 2003; Eme and Laville 2006); their legal form is not the basic criteria to define solidarityeconomy initiatives.

The aim of social entrepreneurship, as it is generally understood, is to create a profitable, market-oriented and innovative economic activity responding to social or environmental needs in the framework of a private initiative serving the general interest. In principle, at least part of the economic surpluses is reinvested into the social mission. In France, Spain and Portugal, the notion of social entrepreneurship is closely related to that of "social entrepreneur", which, as suggested by Mair and Marti (2006), focuses on the individual characteristics of the entrepreneur and on his/her behaviour. In the rest of this chapter, when mentioning "social entrepreneurship", we will bear this focus in mind.

Within this context, our aim is to identify what types of organisations could be considered as social enterprises in France, Portugal and Spain. Using the EMES ideal type of social enterprise as a basis to delineate the SE field in the three countries, we adopt a systemic and comparative point of view. The systemic approach drives us to analyse social enterprise as part of a system of interactive institutional agents. The comparative approach helps us to understand the common responses, materialised in SE models, to similar transformation processes of the environments.

This chapter is structured in four parts. First, we present our analytical framework, building upon an institutional perspective. In the second part, we briefly present the institutional and economic environments in France, Spain and Portugal, with a view to better understanding and comparing these countries. The third part identifies and presents the different SE models in the three countries. The last part concerns our major conclusions.

\subsection{An Institutional Framework}

One of the most consolidated theoretical approaches employed in the field of the social economy is provided by institutional theory (Powell 
and DiMaggio 1991; Scott 1995: 33). It suggests that institutions consist of cultural-cognitive, normative and regulative structures, activities and resources that provide stability and meaning to social life. Institutional environments are "characterised by the elaboration of rules and requirements to which individual organisations must conform in order to receive legitimacy and support" (Scott 1995: 132).

Institutional environments have a significant influence on the emergence and implementation of social initiatives (Borzaga and Defourny 2001; Mair and Marti 2006; Salamon and Sokolowski 2010; Kerlin 2013).

Our hypothesis is that institutional factors and organisational inertia have led social enterprises into a path-dependent process, in the sense that solutions adopted by social enterprises today are contingent on the past and on their institutional environment, and that they are selfreinforcing, leading to the persistence of social-economy traditions. However, we complete our analysis by introducing the agency and organisational levels into our study of the dynamics observed. We adopt a point of view based on a path-creation dynamic, considering that "actors mobilise the past not necessarily to repeat or avoid what happened but instead to generate new options" (Garud et al. 2010: 770). In other words, initial conditions are not simply imposed onto but "enacted" by the actors; indeed, although actors are embedded in their environment, contingent elements of the institutional environment are seen more as opportunities for new actions than as factors limiting them.

Building upon Skelcher and Smith (2015: 439), we consider SE models from an institutional-logic approach, as "contingent settlements between plural institutional logics within one organisational entity”. Each model is the result of the interaction between historical contingency, normative frames, organisational form and individual agency.

We analyse both the evolution of the institutional environment and that of the organisational fields in which social enterprises are embedded. We consider that path creation (or institutional creation) occurs when changes are observed within the field's boundaries (for instance when new entrants arrive in the field) or in the governance structures. Emerging SE models contribute to these changes in the organisational field (Scott et al. 2000: 24-25).

\subsection{Comparative Analysis of Environmental Evolutions: A Long Process of Institutionalisation Leading to Path Dependence}

While the relative size of the social economy is larger in France (around $10 \%$ of total employment) than in Spain (around 7\%) and Portugal (around 6\%), this sector has existed for a long time in all three countries, and it has undergone a long process of institutionalisation, a milestone of which was the adoption of a law dedicated to the social economy. ${ }^{1}$ 


\section{Petrella, Richez-Battesti et al.}

This process of institutionalisation has been deeply marked, in all three countries, by a tradition of collaboration between social-welfare social-economy organisations and public authorities in relation to the expansion of the welfare state. France is characterised by a corporatist welfare-state regime relying on social-security contributions from employers and employees and on the presence of associations, which benefit from significant public support and are major providers of social services, complementing public provision. Spain and Portugal have a Mediterranean welfare-state regime, characterised by the presence of elements of corporatism and gaps in terms of protection; the welfare system developed belatedly, the role of civil society is limited and social organisations show a strong dependence on public administrations (Ruiz Olabuenaga 2006; Ferreira 2015).

The change in the political scene and the new economic situation in Spain during the 1970s led to the rise of social-economy organisations and generated new dynamics in their relations with the state. Four phases can be distinguished in the evolution of social-economy entities in the country. The first phase, namely the phase of emergence (1970-1980), refers to the period when, following the fall of the dictatorial regime, Spanish civil society emerged with a renewed and mobilising strength. The second phase, namely that of consolidation (1980-1990), occurred after the political transition. Once democracy was established, a strong social demobilisation followed; it caused a transformation of the socialeconomy sector into organisational forms that were more "stable" (to the extent that they corresponded to legally recognised forms) but were characterised by low economic resources and poor social leadership. A phase of expansion (1990-2000) followed, during which a significant number of social entities became services providers for the public administration. Finally, the institutionalisation phase (from 2000 onward) started when legislation for the sector was adopted; the sector became recognised as a legitimate interlocutor for public and private bodies (Rodríguez Cabrero 2003).

In Portugal, social-economy organisations already existed in the 19th century, but the dictatorship (1926-1974) limited their development until the Democratic Revolution. As in Spain, the social economy then re-emerged and evolved towards an increasing role for some organisations in the provision of social services and an increasing number of organisations. Nevertheless, the field remained fragmented until 2010. With the support of the government and political parties and the mobilisation of the main actors of the sector, a range of bodies and policies dedicated to the social economy were set up then, including the Framework Law on the Social Economy. A new institutional path was initiated, reinforced by latent institutional elements (Ferreira 2015). The concepts of "solidarity economy" and "social enterprise", though, were left outside the Framework Law on the Social Economy. 
France adopted a similar path of institutionalisation of what is now referred to as the "social and solidarity economy". Although the concept of social economy had already appeared in the 19th century, its development is inseparable from the emergence of the state/market synergy during the "Glorious Thirty", that is, the 30 years (from 1945 to 1975) following the end of World War II, which were marked by rapid economic growth in France. The social economy became stabilised as a set of organisations whose operating rules were distinct from those of commercial enterprises, but their scope remained limited. In 1981, social-economy organisations (mutual societies, cooperatives and associations), which had expanded, were recognised as belonging to a common sector through a "Charter of the social economy". After 1981, the social economy was consolidated, but with a tendency towards banalisation and isomorphism with either commercial enterprises (for cooperatives in particular) or public services (for welfare-services associations). The solidarity economy emerged in a context of crisis in reaction to these tendencies; it emphasised participation and social transformation. The alliance of the social economy and the solidarity economy appeared necessary to strengthen their position in the dialogue with public bodies; a compromise was reached in the 2000s on the term "social and solidarity economy" (SSE), which was consolidated by the Law on the Social and Solidarity Economy in July 2014 (for more details, see Fraisse et al. 2016). This process has structured the relationship of the French SSE with the public sector, providing the system with greater stability.

In the three countries, the institutionalisation process has also led to the regulation of social-economy organisations, to their diversification and increasing complexity, and to a trend towards their professionalisation and specialisation, in particular for welfare-services associations. In Spain and France, during the last two decades, social-economy organisations have evolved from voluntary-based associations to more professionalised and efficient ones. In Portugal, a similar trend has been at work since the 1980s, due to the combined effect of the central role of these organisations in the welfare state and of the scarcity of state funding. Since the 2010s, there has been a shift from a discourse emphasising social-economy organisations' role in social welfare to a discourse focusing on their role in the economy (Ferreira 2015).

Many organisations have become service-providing non-profit "businesses", increasingly giving importance to their members' professional qualification and replacing volunteers with paid workers (Salinas Ramos 2001; Rodríguez Cabrero 2003). The main sources of funding are however still public grants (Pérez Diaz and López Novo 2003; Marbán Gallego and Rodríguez Cabrero 2006) or a combination of public grants and user fees (Ferreira 2015).

From these perspectives, most social-economy organisations have revisited their models to adapt to their new environment. 


\section{Petrella, Richez-Battesti et al.}

\subsection{Models of Social Enterprise}

As a result of the evolution of institutional environments in the three studied countries, organisations meeting the EMES indicators of the ideal-typical social enterprise are mostly-but not only-social-economy organisations that had to adapt and experiment new organisational forms and new ideas. Different responses are identified along the axis between path dependence and path creation.

We identify four SE models, which are similar in the three countries. Indeed, although each model presents country-specific features, the transformation processes of traditional legal forms have been similar in France, Portugal and Spain. The first model includes specific forms of cooperatives, with more explicit social or general-interest goals than traditional cooperatives. The second model corresponds to entrepreneurial non-profit organisations, that is, associations (and some foundations) that carry out economic activities and strengthen their entrepreneurial dimension. The third model concerns WISEs, which have deeply changed in the last decade. The last model consists of social businesses or emerging forms of social enterprise-not all of which are considered to be part of the social economy.

\subsubsection{Social or General-Interest Cooperatives}

Historically, cooperatives were those social-economy organisations that typically carried out an economic activity on the market. Traditional cooperatives were mainly governed by one type of stakeholder (workers, consumers, producers). However, as in many other European countries, the need to take into account the interests of a plurality of stakeholders and to pursue a general-interest purpose under a cooperative form has gradually emerged in France, Spain and Portugal in the last decades.

In France, this led to the creation, in 2001, of a new legal form, namely the "collective-interest cooperative" (société coopérative d'interêt collectif, or SCIC). The objective of SCICs is the provision of goods or services of collective interest that have a social-utility character (Law of 17 July 2001). The economic activity is carried out to the benefit of the community rather than to the benefit of the organisation's members alone, and the social-utility character of the production is recognised by public authorities. This cooperative legal framework requires a multiplestakeholder ownership, with a governance by several possible "colleges", rooted in the territory in which they operate and representing the collective-interest dimension of the cooperative (Fraisse et al. 2016). Another new cooperative legal form was adopted in France and recognised by law in 2014 (Fraisse et al. 2016), namely the "activity and employment cooperative" (coopérative d'activité et d'emploi, or CAE), which aims to create jobs and support the creation and development of 
economic activities. The CAE is an original form: its members' status combines characteristics of the status of entrepreneur and of that of paid worker.

In Spain, national Law 27/1999 on Cooperatives recognises twelve types of cooperatives. Beside these types, the law introduces the status of social-initiative cooperative, which can be granted to any cooperative belonging to one of the twelve types (Solórzano-García et al. 2018a), provided that it meets the following requirements:

- The cooperative must be non-profit.

- The cooperative's social purpose must be to provide welfare services in health-related, educational, cultural or other activities of a social nature; or to develop any economic activity whose object is the work integration of people suffering from any kind of social exclusion; or, more generally, to satisfy social needs left unmet by the market.

In addition to national-level legislation, Spanish regional communities can develop their own legal framework for cooperatives, thereby introducing different approaches to social-initiative cooperatives. These initiatives can thus be referred to by different terms in the different regions-"social-interest", "social-integration", "social-services" or "social-welfare" cooperatives. The regulative framework for these initiatives is the relevant regional legislation.

In Portugal, the legislation has been slow to adapt to the emergence of cooperatives oriented towards the general interest. In legal terms, the only cooperative branch where cooperatives are assumed to be oriented towards the general interest is that of social-solidarity cooperatives, created in 1997 in the Cooperative Code, and inspired by a specific type of cooperative set up in 1975, namely the "cooperative for the education and rehabilitation of citizens with disabilities" (cooperativa de educação e reabilitação de cidadãos com incapacidade, or CERCI) (Perista 2001). CERCIs provide social services to vulnerable groups and communities, access to education, training and work inclusion. They have multistakeholder governance, involving workers and users. Another specific type of cooperative, namely that of public-interest cooperatives, legally created in 1984, is also characterised by a multi-stakeholder nature; another distinctive trait of these initiatives lies in the fact that they include public bodies among their members. On the other hand, cultural and consumption cooperatives may apply for the public-benefit status. Since 2000s there has been a blossoming of new cooperatives with environmental and local-sustainability missions that are framed in the traditional cooperative branches, and many describe themselves as pertaining to the solidarity economy. A change in the Cooperative Code in 2015 introduced the possibility to include, as full members of the cooperative, investors who contribute only with funding. This was also 
associated with a move towards market models as, in certain cooperative branches, the possibility of linking the voting power to the amount of shares owned was established for cooperatives with more than 20 members.

These examples illustrate the move from traditional, mutual-interest cooperatives to more social- or general-interest forms, as well as a move towards market models. The multi-stakeholder (instead of singlestakeholder) ownership and the collective (instead of mutual) interest can be seen as new institutional options for the cooperative form. These evolutions concern not only the regulatory dimension but also the normative and cognitive ones, since they lead to the emergence of new rules and new norms within the cooperative world. As cooperatives also involve new stakeholders, forms of path creation can be identified in terms of new alliances with public or commercial actors, who are offered the possibility to become members. Last but not least, these new organisational forms of cooperatives, in particular those with a clear social aim (social welfare, social services or job creation), contribute to redesigning public policies. Some others adopt a societal aim linked with the solidarity-economy movement.

\subsubsection{Entrepreneurial Non-Profit Organisations}

In France, Spain and Portugal, social services and neighbourhood services have hitherto been provided, to a large extent, by non-profit organisations (NPOs), which gained new impetus in the 1980s and 1990s.

The institutional developments of the 2000s led some segments of the non-profit sector to evolve in a more entrepreneurial direction and to change scale to position themselves on the market and better stand up to the growing competition.

In Spain, for the last several years, there has been a decline in the financial resources of the non-profit sector's entities. Partly due to a decline in support from the private sector (whose total amount has decreased by $11.7 \%$ between 2010 and 2013) and from the public sector, the total financial support to the non-profit sector has been reduced by $22.4 \%$ between 2008 and 2013. This has led to a change in this sector's revenue-raising strategies, which have become more oriented to selffinancing. In fact, self-financing from market activities increased by $47 \%$ between 2008 and 2013 (Solórzano-García et al. 2018b).

In France, the increase in public-procurement practices made up to some extent for the decrease in the traditional mode of financing by grants (Tchernonog and Prouteau 2019). Indeed, the share of public contracts in NPOs' total resource mix increased from $17 \%$ in 2005 to $24 \%$ in 2017 , while the proportion of public grants fell from $34 \%$ to $20 \%$. Such trends call NPOs' project into question, whenever their role becomes restricted to managing local services of general interest, defined 
in a top-down way by public authorities in the framework of public procurement and through managerial requirements. This evolution, combined with the entry of for-profit enterprises into sectors such as those of home-care services (Petrella 2012) or child-care services (Petrella et al. 2014), has led to a diversification of NPOs' strategies to such an extent that it is now sometimes difficult to describe the non-profit sector as a coherent whole. Several strategies of growth (through mergers or takeovers), mutualisation or grouping (through membership in a federation or the creation of territorial or sectoral networks) have been observed within the non-profit sector and have radically changed the structure of supply across the French territory (Richez-Battesti and Malo 2012).

These strategies, which have also been observed in Spain (Marbán Gallego and Rodríguez Cabrero 2013), are accompanied in both countries by cost-cutting rationalisation procedures and by the professionalisation of staff, governance bodies and management tools in most organisations. While this managerial and entrepreneurial turn now predominates in some sectors, it should also be stressed that not all nonprofit organisations have gone so far in this direction.

In Portugal, there is a close relationship between the welfare state and NPOs, which act as providers of social services and have developed gradually since the 1980s and more intensively since the end of the 1990s, as the state invested in this area. Since the 1990s, the offer of family social services (in terms of number of creches and care houses) increased substantially, as did the number of non-profit and for-profit providers. Social-service NPOs are awarded the special status of "private social-solidarity institution" (instituição particular de solidariedade social, or IPSS), and their relationship with the state is framed under a type of contract (namely cooperation agreements) mostly negotiated at the national level between the government and the umbrella bodies. Still, the share of state funding in NPOs' total income $(31.8 \%)$ is lower than the share of sales and user fees (63.6\%) (INE/CASES 2016), and it does not currently cover staff costs. The crisis that started in 2008 affected users' employment and income, which in turn impacted their ability to pay their share; as a result, many organisations have gone through — and are still undergoing-financial problems and are attracted to social entrepreneurship conceived as market-based earned-income strategies (Parente 2014). The new public-procurement rules for reserved contracts, in force since 2017, bring about competition among nonprofits as well as contractual arrangements that are more similar to market-based ones. Another subgroup of NPOs, more territorially oriented to local development, has been shaped by EU policies; they mostly operate under project funding and resort to commercial sources of funding as a complementary source of income. A recent development in this subsector is the development of these organisations' relation with the 
solidarity economy, for instance through gathering under the new solidarityeconomy network (Rede Portuguesa de Economia Solidária, or RedPES).

From the analysis of the French, Spanish and Portuguese cases, we identify a relatively common experience characterised by (1) the strengthening of NPOs' role as providers of services, which implies a progressive professionalisation of the non-profit sector; (2) a relative loss of NPOs' civic/political function; (3) a greater selective competition with the for-profit sector, simultaneously with the development of various forms of cooperation to develop social-inclusion projects; (4) an increasing competition among non-profit organisations, due to funding reductions, but with the emergence of new forms of cooperation and networking; and (5) a reorientation of social work, due to the emergence of new social needs, which demand more complex interventions.

In brief, the resource mix of entrepreneurial NPOs has changed deeply. Some of them grew in size and scale. In some cases, the social or political project and governance were also redefined with the aim of maintaining a strong civic or community-based institutional logic; some of them did so by adopting the principles of the solidarity economy. Relationships among organisations changed dramatically, and the boundaries of the sector changed as well with the entrance of for-profit enterprises in fields that had traditionally been occupied only by public or non-profit organisations. These elements can be interpreted as reflecting institutional creation, with new alliances with the for-profit sector and a more entrepreneurial mindset and management. Through their commitment to meet new or unmet social needs and their search for new financial resources, non-profit organisations contribute to the renewal of social policies and to blurring frontiers between the private, public and non-profit sectors. The emerging path they are charting is not without risk for themselves, since it can affect their very nature, based on voluntary engagement and on democratic principles, and their embeddedness in local and community networks. This (re)orientation of NPOs towards the market economy can also be observed amongst those adhering to the solidarity-economy framework, which is characterised by a stronger emphasis on experimenting with alternatives to the market economy.

\subsubsection{Work-integration social enterprises}

Work-integration social enterprises are no doubt one of the oldest SE models; the first WISE emerged in France in the late 1970s (Gardin et al. 2012), in Spain in the 1980s (Álvarez Vega 1999) and in Portugal in 1983 (Perista and Nogueira 2002). These organisations were progressively institutionalised in the 1990s as an instrument of employment and integration policies.

In France, the term used to refer to WISEs is "organisations for integration through economic activity” (structures d'insertion par l'activité économique). 
Today, four main types of WISE coexist and are recognised by the law on the social and solidarity economy: two of these types correspond to productive types of organisation (namely work-integration enterprises, or entreprises d'insertion, and work-integration workshops and work sites, or ateliers et chantiers d'insertion), while the other two types correspond to organisations that second workers to other organisations (intermediate voluntary organisations, or associations intermédiaires, and temporary work integration enterprises, or entreprises de travail temporaire d'insertion).

Most of these organisations are still operating under an associative (non-profit) legal form, but some adopt a commercial legal form. Some of the historic leaders of the work-integration field define themselves as social entrepreneurs; they are among the founders of the "Movement of social entrepreneurs" (Mouvement des entrepreneurs sociaux, or Mouves), a network of social entrepreneurs created in France in 2010. This "filiation" between work-integration enterprises and social entrepreneurship can be seen as a symptom of a mutation of the work-integration sector, moving beyond a mere role of "intermediation" on the labour market. The 2014 Law on the Social and Solidarity Economy clearly recognises WISEs as belonging to the field of the social and solidarity economy.

In Spain, two main types of WISE are recognised by law: WISEs targeting socially excluded groups, named "work-integration enterprises" (empresas de inserción, or EIs) and WISEs targeting people with disabilities (sheltered integration workshops), referred to as "special employment centres" (centros especiales de empleo).

EIs are regulated by national Law 44/2007. Autonomous communities also have some laws about EIs, which are more detailed developments of the national law. EIs have to be set up as trading companies (possible legal forms thus also include worker-owned companies or cooperatives) and, in order to be officially recognised as EIs, they have to meet specific criteria $(51 \%$ of their social capital must be held by a social organisation or a non-profit entity; more than $30 \%$ of their workforce- $50 \%$ from their fourth year of existence onwards-must be workers engaged in the employment integration process; and they cannot distribute more that $20 \%$ of their benefits); they have to develop an economic activity; and their main objective must be the integration and training of people who are at risk of social exclusion.

The second type of Spanish WISEs, namely special employment centres, was initially established by Law 13/1982 with the aim of pursuing the social integration of people with disabilities into the open employment market. They can adopt any legal form, and their owner(s) can be any natural or legal-public or private-person. They perform productive work, participate in commercial operations, and aim to provide remunerated positions and adequate personal and social services for workers with disabilities (who must constitute at least $70 \%$ of their staff). 
Like Spain, Portugal has work-integration enterprises for people who experience difficulty in gaining access to the labour market, and sheltered employment centres for people with disabilities. However, the Portuguese field of work integration is currently weak, unstructured and unrecognised.

Portuguese work-integration enterprises were set up in the context of a public policy that was terminated in 2015; they have experienced a sharp decline, from 512 in 2004 (Quintão 2008) to only a few enterprises nowadays (exact numbers are not known). Seventy-eight percent of workintegration enterprises were set up by NPOs; some of those that have survived until today have evolved to become non-profit's departments, and a few have become autonomous organisations. The only remaining public policy promoting this type of WISE and a network bringing together seventeen of these enterprises (which describe themselves as pertaining to the solidarity economy) are to be found in the region of Azores.

The second type of Portuguese WISEs, namely sheltered employment centres, are productive structures, most of which do not have an autonomous legal status: they are production units within not-for profit organisations. According to available information, there are less than ten sheltered employment centres in the country. Given the preference of public policy for work integration into the regular labour market, the core of the work carried out by social-economy organisations in this field consists of vocational training, work placement and support to the integration of disadvantaged people into mainstream enterprises.

In the three countries, WISEs developed in close relationship with public policies aiming to reintegrate workers on the labour market. In France and Spain, some WISEs adopt for-profit legal forms to access private capital but with strong governance safeguards and strict profitredistribution rules. This leads to the emergence of new organisational forms, highly professionalised and very innovative in the development of new fields of activities, which can be interpreted as a sign of a pathcreation institutional dynamic. In particular, new governance models are created out of traditional structures, such as commercial holdings or companies in which the majority (or a blocking-minority) shareholder is a non-profit organisation (or several NPOs). These new forms of WISEs also changed the relationship with public bodies, in a context of shrinking public subsidies. WISEs, faced with new entrants in their fields of activity, are contributing to institutional creation, changing relationships among stakeholders, and experimenting new alliances and new forms of governance structures.

\subsubsection{The Social-Entrepreneurship Model}

This fourth model of social enterprise generally emphasises the figure of the social entrepreneur, who is an individual with an entrepreneurial 
spirit dedicated to a social purpose. In the three countries under consideration, such individuals are "steeped" in the world of enterprise and understand how it works, but they aspire to producing useful answers in relation to the transformations of society.

Social entrepreneurs sometimes launch their activity in the form of an association and may go on to develop it within the statutory framework of a cooperative (such as a SCIC or a social cooperative) or as an equity company owned by the association from which it sprang or by the entrepreneur. Some of them may opt for the legal form of an equity company from the outset, or transform the original association into an equity company, or the association and the equity company can coexist. With few exceptions, the legal form appears to be secondary to the social mission. In parallel, consultancies and support organisations have emerged progressively since the early 2000s to support social entrepreneurship (also referred to as "social businesses").

The social-entrepreneurship model is probably, among the four models that we have identified, the one that is the least path-dependent on the social-economy tradition. Given the strength and importance of this tradition in the three countries considered, this can explain, at least partly, why there are so few social-business-type enterprises. However, social enterprises of this type, despite their low number, represent an important development, to the extent that they experience a new combination between market and social or societal institutional logics, leaving aside considerations about legal forms and democratic governance principles. This emerging model is a contentious issue in the social-economy sector.

\section{Conclusion}

This comparative work confirmed the relevance of analysing France, Spain and Portugal together, as they share important common features and transformation trends. Nevertheless, for each model, national specificities have also been found; they are linked to each country's particular environment and cultural traditions.

The strong heritage of the social economy and of its institutionalisation process influences the development of social enterprise, supporting the hypothesis of the existence of a path dependence that could be one reason why the "social-entrepreneurship" model (which, unlike the other three models, is not rooted in the social economy) has not developed-or only marginally - until now. As the models identified above show, most French, Portuguese and Spanish social enterprises are anchored, if not included, in the social economy. Indeed, the ecosystem created in the three countries to support the development of social-economy organisations contributes to the strong proximity of social enterprises with the social economy.

The three laws on the social economy aim to clarify the principles that characterise this sector and to define its boundaries in a changing 
environment. As far as the boundaries are concerned, the comparison shows some differences in the way commercial enterprises are considered. After several debates and consultations, it was decided, in France, to include commercial enterprises that meet certain governance and profitdistribution criteria in the social economy; by contrast, the Spanish and Portuguese parliaments chose to adopt a less inclusive approach.

But beyond this difference, social-economy principles remain predominant in the SE models identified during our study in the three countries. Democratic governance and limited profit distribution (for instance through an asset lock), included in the three laws, remain central to be recognised as a social enterprise in France, Spain and Portugal, since social enterprises are considered to be part of the social economy. The only exception is the small share of commercial enterprises with a social aim (which are part of the social-entrepreneurship model) that do not fulfil these criteria and are outside the social economy. By contrast with other approaches to social enterprise, which give priority to the social mission and to the entrepreneurial dimension, France, Spain and Portugal share the view that the social aim and social innovation are not sufficient for an organisation to be considered as a social enterprise.

Although, at first sight, the law can be considered to reduce the number of possible evolutionary trajectories, three out of the four SE models in the three countries studied can be seen as innovative or revisited models from the social economy, and as different strategic responses to face new environmental constraints. Among those constraints, cutbacks in public grants (and, in the case of France and Spain, the transformation of these grants into contracting-out processes) or the introduction of new performance and quality requirements have generated important organisational pressures. In general, these "new" forms of social-economy organisations, in comparison with their "traditional" counterparts, demonstrate a higher degree of professionalism; are more market-oriented; hybridise, on a larger scale, public and private resources; and involve, more frequently, multiple stakeholders. These evolutions can be understood as new options generated by the actors, in a path-creation process (Garud et al. 2010), while building upon the past. Institutional creation concerns new legal forms or institutional arrangements (such as mergers that change the boundaries of existing organisations), new governance models (e.g., implementing democracy in new ways), new resource mixes, new professions and more professionalised practices. At the organisational field level, important institutional creation has been highlighted in terms of changing relations among field organisations (with a nearly general increase of competition among them) and changing boundaries of the social economy (with the inclusion of some forprofit social enterprises) and of some activity fields, such as social services, where boundaries with the for-profit sector become blurred. The emergence of "social-economy-based" social enterprises illustrates the fact that, although the environment is complex and generates path dependence, the 
creativity and innovation demonstrated by some actors have led to the generation of new institutional paths for social enterprises.

These models are, in the end, not very different from the four SE models identified by Defourny and Nyssens (2017) in the ICSEM Project. We argue, however, that some characteristics of these models are specific to the countries considered, as they are linked to the "anchorage" of social enterprise in the social economy. As far as entrepreneurial non-profits are concerned, they are characterised in France, Portugal and Spain by a trend towards professionalisation and by their resource hybridisation (with a larger part of resources coming from public contracts), rather than by characteristics that can be observed in other countries, such as an increase in the share of market resources in their resource mix, the development of mission-unrelated activities, the creation of for-profit subsidiaries or an increased reliance on philanthropic and sponsoring resources. Social or general-interest cooperatives were created in Portugal, Spain and France after their emergence in Italy, but sooner than in other countries; this could be accounted for by the existence of a particularly strong cooperative tradition in these countries. Unlike Defourny and Nyssens (2017) in their identification of SE models at the global level, we have considered WISEs as a separate model, since they have followed their own development path, with roots in the associative sector (rather than in the cooperative one) and a relatively strong reliance on public policies supporting work integration. Finally, the fourth model-namely that of commercial social enterprises-is, at least for the time being, less developed than in other countries. It should also be noted that we have not identified any publicservice spin-off that could be considered as a social enterprise. Altogether, the social-economy tradition and specific interactions with public policies give a specific "colour" to the SE phenomenon in France, Portugal and Spain. These elements could also apply to Belgium and, to some extent, to Italy, where the social economy has also a long tradition. In countries where the social economy has long played an important role, the institutionalisation of this sector may have contributed to frame the development and the understanding of social enterprises.

\section{Note}

1 A detailed description of the French, Portuguese and Spanish legal frameworks can be found in chapters 4,11 and 12 , respectively.

\section{References}

Álvarez Vega, M. I. (1999) "Las empresas de inserción social como nueva forma de organización empresarial. Especial referencia a su régimen jurídico", CIRIEC-España, Revista de Debate sobre Economía Pública, Social y Cooperativa, Vol. 31, pp. 47-84. 
Borzaga, C. \& Defourny, J. (2001) The Emergence of Social Enterprise, London: Routledge.

CEP-CMAF (2002) Final Common Declaration of the European Organisations of Social Economy, Brussels, June 20.

CWES (1990) Rapport à l'Exécutif Régional Wallon sur le secteur de l'Économie Sociale, Liege: Conseil Wallon de l'Économie Sociale.

Dacheux, E. \& Laville, J.-L. (2003) Économie solidaire et démocratie, Meudon: Hermès, Vol. 36.

Defourny, J. (2004) “L'émergence du concept d'entreprise sociale", Reflets et Perspectives, Vol. XLIII, No. 3, pp. 9-23.

Defourny, J. \& Nyssens, M. (2017) "Fundamentals for an international typology of social enterprise models", Voluntas, Vol. 28, pp. 2469-2497.

Eme, B. \& Laville, J.-L. (2006) "L'économie solidaire", in Laville, J.-L. \& Cattani, A. D. (eds) Dictionnaire de l'autre économie, Paris: Gallimard, coll. "Folio", pp. 303-312.

Ferreira, S. (2015) "New paths for third-sector institutions in a welfare state in crisis: The case of Portugal", Nonprofit Policy Forum, Vol. 6, No. 2, pp. 213-241.

Fraisse, L., Gardin, L., Laville, J.-L., Petrella, F. \& Richez-Battesti, N. (2016) "Social enterprises: at the crossroads of social economy, solidarity economy and social entrepreneurship?”, ICSEM Working Paper Series, No. 34, Liege: The International Comparative Social Enterprise Models (ICSEM) Project.

Gardin, L., Laville, J.-L. \& Nyssens, M. (2012) Entreprise sociale et insertion, Une perspective internationale, Paris: Desclée De Brouwer.

Garud, R., Kumaraswamy, A. \& Karnøe, P. (2010) "Path dependence or path creation?", Journal of Management Studies, Vol. 47, No. 4, pp. 760-774.

INE/CASES (2016) Conta Satélite da Economia Social 2013, Lisbon: INE/CASES.

Kerlin, J. A. (2013) "Defining social enterprise across different contexts: A conceptual framework based on institutional factors", Nonprofit \& Voluntary Sector, Vol. 42, $\mathrm{n}^{\circ} 1$, pp. 84-108.

Mair, J. \& Marti, I. (2006) "Social entrepreneurship research: A source of explanation, prediction, and delight”, Journal of World Business, Vol. 41, No. 1, pp. 36-44.

Marbán Gallego, V. \& Rodríguez Cabrero, G. (2006) "Estado de bienestar y tercer sector social en España. El estado de la investigación social”, CIRIEC-España, Revista de Economía Pública, Social y Cooperativa, Vol. 56, pp. 117-139.

Marbán Gallego, V. \& Rodríguez Cabrero, G. (2013) "Sistemas mixtos de protección social. El tercer sector en la producción de bienestar”, Presupuesto y Gasto Público, Vol. 71, pp. 61-82.

Parente, C. (ed.) (2014) Empreendedorismo social em Portugal, Porto: Universidade do Porto, Faculdade de Letras.

Pérez Diaz, V. \& López Novo, J. P. (2003) El Tercer Sector Social en España, Madrid: Ministerio de Trabajo y Asuntos Sociales.

Perista, H. (2001) "Co-operatives for rehabilitation of people with disabilities", In Borzaga, C. \& Defourny, J. (2001) The Emergence of Social Enterprise, London: Routledge.

Perista, H. \& Nogueira, S. (2002) "National profiles of work integration social enterprises: Portugal”, EMES Working Papers Series, No. 02/09, Liege: The International EMES Research Network. 
Petrella, F. (ed.) (2012) Aide à domicile et services à la personne. Les associations dans la tourmente, Rennes: Presses Universitaires de Rennes, pp. 9-22.

Petrella, F., Richez-Battesti, N., Laurent, A., Chanut-Guieu, C. \& Lhuillier, V. (2014) "La construction sociale de la qualité dans les services d'accueil collectif du jeune enfant. Pluralité de modèles d'organisation et enjeux de gouvernance", Politiques sociales et familiales, Vol. 116, pp. 39-52.

Powell, W. \& DiMaggio, P. (eds) (1991) The New Institutionalism in Organizational Analysis, Chicago: University of Chicago Press.

Quintão, C. (2008) "Dez anos de empresas de inserção em Portugal-revisão dos dados oficiais e de estudos recentes", Paper presented at the VI Congresso Português de Sociologia, Lisbon, 25-28 June.

Richez-Battesti, N. \& Malo, M.-C. (2012) "ESS et mutations organisationnelles", RECMA - Revue Internationale de l'Economie Sociale, Vol. 325, pp. 36-47.

Rodríguez Cabrero, G. (ed.) (2003) Las entidades voluntarias de acción social en España, Madrid: Fundación FOESSA.

Ruiz Olabuenaga, J. I. (ed.) (2006) El sector no lucrativo en España. Una visión reciente, Bilbao: Fundación BBVA.

Salamon, L. \& Sokolowski, S. (2010) “The social origins of civil society: Explaining variations in the size and structure of the global civil society sector", Paper presented at the 9th International Conference of the International Society for Third Sector Research, Istanbul, July 7-10.

Salinas Ramos, F. (2001) "El sector no lucrativo en España: Características de una evolución”, Anuario de estudios cooperativos, Vol. (1), pp. 269-302.

Scott, W. R. (1995) Institutions and Organizations. Ideas, Interests and Identities, New York: Sage Publishing.

Scott, W. R., Ruef, M., Mendel, P. J. \& Caronna, C. (2000) Institutional Change and Healthcare Organizations: From Professional Dominance to Managed Care, Chicago: The University of Chicago Press.

Skelcher, C. \& Smith, S. R. (2015) “Theorizing hybridity: Institutional logics, complex organizations, and actor identities: The case of nonprofits", Public Administration, Vol. 93, No. 2, pp. 433-448.

Solórzano-García, M., Guzmán Alfonso, C., Savall Morera, T. \& Villajos Girona, E. (2018a) "Identidad de la empresa social en España: análisis desde cuatro realidades socioeconómicas", CIRIEC-España, Revista de Economía Pública, Social y Cooperativa, Vol. 92, pp. 155-182.

Solórzano-García, M., Navío-Marco, J. \& Valcárcel-Dueñas, M. (2018b) "Impact measurement for social innovation: Analysis of the Spanish third sector”, in La Torre, M. \& Calderini, M. (eds) Social Impact Investing Beyond the SIB, Basingstoke: Palgrave Macmillan, pp. 195-209.

Tchernonog, V. \& Prouteau L. (2019) Le paysage associatif français, mesures et évolutions, 3rd edition, Lyon: Juris-Editions Dalloz. 